\title{
Use of zinc-rich primers co-pigmented with phosphates applied on rusty steel surfaces contaminated with soluble salts
}

\author{
D. de la Fuente*, B. Chico* y M. Morcillo*
}

\begin{abstract}
Zinc-rich primers (ZRP) offer good anti-corrosive behaviour, and are an ecologically acceptable solution, when applied on carbon steel substrates that are rusted and contaminated with soluble salts (chlorides and sulphates), provided certain critical contamination thresholds are not exceeded. The use of phosphate-type co-pigments in ZRP formulations, could lead to an increase in tolerable critical levels for soluble salts. This work discusses the results of a comparative study carried out with ZRP and non-ZRP systems incorporating various types of co-pigments in several concentrations, applied on substrates contaminated with different chloride and sulphate levels. The study considers the results of atmospheric exposure test (24 months in Madrid atmosphere) and of accelerated humidity condensation tests.
\end{abstract}

Keywords Rusty steel. Soluble salts. Zinc rich primers. Pigments. Osmotic blistering.

\section{Empleo de imprimaciones ricas en zinc co-pigmentadas con fosfatos aplicadas sobre superficies de acero herrumbrado contaminado con sales solubles}

\begin{abstract}
Resumen Las imprimaciones ricas en zinz (IRZ) ofrecen un buen comportamiento, además de ser una solución ecológicamente aceptable, cuando se aplican sobre substratos de acero al carbono herrumbrado y contaminado con sales solubles (cloruros y sulfatos), siempre que no se superen ciertos umbrales críticos de contaminación. El empleo en la formulación de las IRZ de copigmentos de tipo fosfato podría suponer un aumento en los niveles críticos tolerables de sales solubles. En el presente trabajo se discuten los resultados del estudio comparativo llevado a cabo con sistemas IRZ y no IRZ con diferentes tipos de estos copigmentos en varias proporciones, aplicados sobre substratos contaminados con distintos niveles de cloruros y sulfatos. El estudio incluye los resultados tanto del ensayo de exposición atmosférica ( 24 meses en la atmósfera de Madrid) como el ensayo acelerado de condensación de humedad.
\end{abstract}

Palabras clave Acero herrumbrado. Sales solubles. Imprimaciones ricas en zinc. Pigmentos. Ampollamiento osmótico

\section{INTRODUCTION}

One of the most frequent causes of premature failure of anticorrosive paint coatings applied on steel structures is the presence of soluble salts, mainly chlorides and sulphates, at the metal/paint interface.

These salts are found among the steel corrosion products and have their origin in the exposure of the steel, prior to its painting, in environments containing these aggressive species. The rapid deterioration of the paint system is shown by the early appearance of blistering of the film. This cause-effect relationship was first reported by Mayne in $1959^{[1]}$.

The blistering phenomenon is a consequence of the verification of osmotic processes through the paint membrane, due to the existence of soluble compounds at the interface, and of accelerated corrosion of the steel below the organic coating, caused by the aggressive ions $\left(\mathrm{Cl}^{-}\right.$and $\left.\mathrm{SO}_{4}{ }^{2-}\right)$. The problem appears mainly when the paint is applied on rusted steel.

Painting technology for the application of paints on rust has traditionally turned to lead orthoplumbate base pigments (red lead oxide) in oil type vehicles,

(*) National Centre for Metallurgical Research. CENIM (CSIC). Avda. Gregorio del Amo, 8. 28040-Madrid (Spain). 
Use of zinc-rich primers co-pigmented with phosphates applied on rusty steel surfaces contaminated with soluble salts

D. DE la Fuente, B. CHICO y M. MORCILlo

with a good wetting power, with fairly acceptable results. However, ecological considerations now rule out the use of lead base pigments.

The alternatives currently available for this situation are:

a) Use of very thick coatings (mastics) that impede the entry of water and oxygen molecules through them. They present the disadvantage of their high cost and complicated application.

b) Use of inerting pigments. The inerting of the aggressive species of rust $\left(\mathrm{Cl}^{-}\right.$and $\left.\mathrm{SO}_{4}{ }^{2-}\right)$ can be achieved by different mechanisms: (i) the formation of insoluble compounds by chemical reaction of the pigment with the saline species ${ }^{[2-5]}$ and (ii) the use of zinc-rich paints (ZRP) $)^{[6-8]}$.

The first studies of the use of inerting pigments ${ }^{[2-5]}$ were published some time ago, and though promising did not lead to the development of commercial products. Nowadays, ecological criteria make it impossible to use the pigments tested in these early studies, since they contained $\mathrm{Cd}, \mathrm{Ba}$ and $\mathrm{Cr}$. However, there are other pigments, such as calcium phosphate, zinc phosphate and zinc-iron phosphate, which do not present these limitations and whose use as co-pigments in ZRPs may improve the anticorrosive behaviour of the latter, permitting an increase in the allowable critical levels of $\mathrm{Cl}^{-}$and $\mathrm{SO}_{4}{ }^{2-}$ at the metal/paint interface.

\section{EXPERIMENTAL PROCEDURE}

In practice, soluble salts are found heterogeneously distributed in the steel corrosion products layer, and frequently located at the base steel/rust layer interface. However, in the studies carried out by most researchers in relation with this issue, with the aim of establishing critical concentration levels or other considerations, the specimens have been prepared by dosing the saline contaminant in a uniform way across unrusted steel surfaces. This situation is rather different to what actually occurs in practice, and is a problem that has already been pointed out by Bayliss and Chandler ${ }^{[9]}$.

In order to resolve this problem, an attempt has been made to reproduce the atmospheric corrosion process of steel in environments contaminated with $\mathrm{SO}_{2}$ and $\mathrm{Cl}^{-}$, using a salt fog cabinet for the case of chlorides and a Kesternich type cabinet for sulphates.
In both cases, specimens of $12.5 \times 8 \mathrm{~cm}$ were cut from carbon steel plate and degreased with acetone.

\subsection{Contamination of specimens in a salt fog cabinet}

After degreasing, the specimens were placed in the cabinet and subjected to salt fog testing according to DIN standard $50021^{[10]}$. Specimens were withdrawn from the cabinet after different exposure times and kept in the laboratory for 2 weeks, during which time a rust layer formed on the specimen surfaces.

\subsection{Contamination of specimens in a Kesternich cabinet}

In the Kesternich cabinet, DIN 50018 ${ }^{[11]}$, the specimens are suspended vertically from a plastic bar. At the bottom of the cabinet a resistor heats a water bath to $40^{\circ} \mathrm{C}$. A volume of $\mathrm{SO}_{2}$ is introduced in the interior of the cabinet. The amount of $\mathrm{SO}_{2}$ introduced was selected as the test variable. A certain volume of $\mathrm{SO}_{2}$ was introduced and after two and a half hours of exposure the test was stopped, and the specimens were removed and kept for 2 weeks in the laboratory.

\subsection{Automatic brushing to remove non-adherent rust}

To remove non-adherent rust from the specimens contaminated with chlorides and sulphates, their surfaces were automatically brushed using a brush with stainless steel bristles of $0.3 \mathrm{~mm}$ diameter and $15 \mathrm{~mm}$ length. The specimens were placed on a support and the brush automatically acted on them horizontally (10 passes in both directions). The specimens were then turned around $180^{\circ}$, with the same side facing upwards, and the brushing process was repeated. Once brushed, the specimens were stored in plastic bags in the laboratory until their painting.

\subsection{Extraction and analysis of chloride and sulphate ion contents}

Three specimens per withdrawal were used to measure the amount of chlorides and sulphates present, following extraction according to the Mayne method ${ }^{[1]}$. The specimens were separately 
immersed in boiling distilled water for $60 \mathrm{~min}$, after which the solutions were filtered and brought to a constant volume for their subsequent analysis.

- Analysis of chlorides: The chloride ions in solution were analysed using the ion selective electrode technique. This technique is based on measuring the change in potential through an ion selective membrane. The magnitude of the change in potential is converted into units of chloride concentration in solution by means of a previously calibrated analyser.

- Analysis of sulphates: The sulphate ions were analysed using the turbidimetric method. This determination is based on ASTM standard D516 ${ }^{[12]}$. The sulphate in solution is transformed into barium sulphate in suspension by the addition of barium chloride in controlled conditions. Using a spectrophotometer the absorbency of the solution is measured in the ultraviolet range (indirect measurement of the degree of turbidity), which is linear with the initial concentration of the sulphate ion in solution. The absorbency readings are compared with a calibration curve previously determined with standard sulphate solutions.

Table I. Chloride and sulphate levels chosen

Tabla I. Niveles seleccionados de cloruros y sulfatos

\begin{tabular}{cc}
\hline Chlorides $\left(\mathrm{mg} / \mathrm{m}^{2}\right)$ & Sulphates $\left(\mathrm{mg} / \mathrm{m}^{2}\right)$ \\
\hline 0 & 0 \\
$50-100$ & 500 \\
$100-200$ & 1500 \\
$200-300$ & 2500 \\
900 & 4000 \\
\hline
\end{tabular}

Table I displays the chloride and sulphate levels chosen for the application of the different paint systems to be studied (Table II).

The paint systems were applied according to their manufacturers' specifications, with thicknesses between 40-60 $\mu \mathrm{m}$. Once the paints had been applied the edges of the specimens were protected and a scribe was made, according to DIN $53167^{[13]}$, on the lower part of those to be exposed in the atmosphere. Table III shows the corrosivity data of the Madrid testing station. Another series of specimens was subjected to cyclic humidity condensation-drying accelerated testing (144 h humidity condensation +24 h drying) in a Cleveland type humidity condensation cabinet, maintaining the temperature between $35-40{ }^{\circ} \mathrm{C}$.

\section{RESULTS}

\subsection{Atmospheric exposure}

Tables IV and V show the degree of blistering of the paint systems after 3, 6, 12 and 24 months of exposure. The values of the size and frequency of blisters, according to ASTM standard D-714 ${ }^{[15]}$, have been converted into numeric values using the Keane conversion table ${ }^{[16]}$.

Table III. Corrosivity data of the testing station

Tabla III. Datos de corrosividad de la estación de ensayo

\begin{tabular}{lc}
\hline Time of wetness (annual fraction) & 0.155 \\
Chloride deposition rate $\left(\mathrm{mg} \cdot \mathrm{m}^{-2} \cdot \mathrm{d}^{-1}\right)$ & 0.9 \\
$\mathrm{SO}_{2}$ deposition rate $\left(\mathrm{mg} \cdot \mathrm{m}^{-2} \cdot \mathrm{d}^{-1}\right)$ & 36.6 \\
$\mathrm{ISO} C$ Corrosivity category* $^{*}$ & $\mathrm{C} 2$ \\
Mild steel corrosion rate $\left(\mu \mathrm{m} \cdot \mathrm{y}^{-1}\right)$ & 18.5 \\
Zinc corrosion rate $\left(\mu \mathrm{m} \cdot \mathrm{y}^{-1}\right)$ & 0.40 \\
\hline
\end{tabular}

* ISO $9223^{[14]}$

Table II. Applied Primers

Table II. Imprimaciones aplicadas

\begin{tabular}{|c|c|c|c|}
\hline & & Systems & \\
\hline Vehicle & Pigment & Vehicle & Pigment \\
\hline Oil (reference) & Red lead oxide & Epoxy-ZRP (reference) & - \\
\hline Epoxy-non ZRP & $\begin{array}{l}\text { Calcium phosphate } 10 \% \\
\text { Calcium phosphate } 20 \% \\
\text { Zinc-iron phosphate } 10 \% \\
\text { Zinc-iron phosphate } 20 \% \\
\text { Zinc phosphate } 10 \% \\
\text { Zinc phosphate } 20 \%\end{array}$ & Epoxy-ZRP & $\begin{array}{l}\text { Calcium phosphate } 5 \% \\
\text { Calcium phosphate } 10 \% \\
\text { Zinc-iron phosphate } 5 \% \\
\text { Zinc-iron phosphate } 10 \% \\
\text { Zinc phosphate } 5 \% \\
\text { Zinc phosphate } 10 \%\end{array}$ \\
\hline
\end{tabular}


Table IV. Degree of blistering after 3, 6, 12 y 24 months of exposure in the Madrid atmosphere for specimens contaminated with known levels of sulphates

Tabla IV. Grado de ampollamiento exhibido por las muestras contaminadas con niveles conocidos de sulfatos tras 3, 6, 12 y 24 meses de exposición en la atmósfera de Madrid

\begin{tabular}{|c|c|c|c|c|c|c|c|c|c|c|c|c|c|c|c|c|c|c|c|c|c|}
\hline \multirow{2}{*}{\multicolumn{2}{|c|}{ Systems }} & \multirow{2}{*}{\multicolumn{4}{|c|}{ Level 0}} & \multicolumn{16}{|c|}{ Sulphates level } \\
\hline & & & & & & \multicolumn{4}{|c|}{ S500 } & \multicolumn{4}{|c|}{$S 1500$} & \multicolumn{4}{|c|}{$\$ 2500$} & \multicolumn{4}{|c|}{5400} \\
\hline Vehicle & Pigment & $\begin{array}{c}3 \\
\text { months }\end{array}$ & $\begin{array}{c}6 \\
\text { months }\end{array}$ & $\begin{array}{c}12 \\
\text { months }\end{array}$ & $\begin{array}{c}24 \\
\text { months }\end{array}$ & $\begin{array}{c}3 \\
\text { months }\end{array}$ & $\begin{array}{c}6 \\
\text { months }\end{array}$ & $\begin{array}{c}12 \\
\text { months }\end{array}$ & $\begin{array}{c}24 \\
\text { months }\end{array}$ & $\begin{array}{c}3 \\
\text { months }\end{array}$ & $\begin{array}{c}6 \\
\text { months }\end{array}$ & $\begin{array}{c}12 \\
\text { months }\end{array}$ & $\begin{array}{c}24 \\
\text { months }\end{array}$ & $\begin{array}{c}3 \\
\text { months }\end{array}$ & $\begin{array}{c}6 \\
\text { months }\end{array}$ & $\begin{array}{c}12 \\
\text { months }\end{array}$ & $\begin{array}{c}24 \\
\text { months }\end{array}$ & $\begin{array}{c}3 \\
\text { months }\end{array}$ & $\begin{array}{c}6 \\
\text { months }\end{array}$ & $\begin{array}{c}12 \\
\text { months }\end{array}$ & $\begin{array}{c}24 \\
\text { months }\end{array}$ \\
\hline Oil (ref) & red lead oxide & - & - & - & - & 7 & 6 & 6 & 4 & $4(s)$ & 2 & w & W & $2(\mathrm{~s})$ & 0 & W & w & $2(s)$ & 0 & w & W \\
\hline \multirow{6}{*}{ EXPOSI-NON PRZ } & Calcium phosphate $10 \%$ & - & $7(\mathrm{~s})$ & 6(s) & 6(s) & $5(s)$ & 2 & w & w & $d(s)$ & 0 & w & w & $5(s)$ & 0 & w & w & n.t. & n.t. & n.t. & n.t. \\
\hline & Calcium phosphate $20 \%$ & - & 9(s) & 6(s) & 4(s) & - & $7(\mathrm{~s})$ & $2(\mathrm{~s})$ & 2(s) & $d(s)$ & 0 & w & w & $5(s)$ & 0 & w & w & n.t. & n.t. & n.t. & n.t. \\
\hline & Zinc-iron phosphate $10 \%$ & - & - & - & - & 9(s) & $7(\mathrm{~s})$ & $4(s)$ & 4(s) & 3 & 0 & w & w & $3(\mathrm{~s})$ & 0 & w & w & 2(s) & 0 & w & w \\
\hline & Zinc-iron phosphate $20 \%$ & - & 8(s) & $7(\mathrm{~s})$ & 6(s) & $7(\mathrm{~s})$ & 5 & w & w & $2(\mathrm{~s})$ & 0 & w & w & $5(s)$ & 0 & w & w & $3(\mathrm{~s})$ & 0 & w & w \\
\hline & Zinc phosphate $10 \%$ & - & - & $7(\mathrm{~s})$ & $7(\mathrm{~s})$ & 9(s) & $8(\mathrm{~s})$ & $5(s)$ & $5(s)$ & $d(s)$ & 0 & w & w & $3(s)$ & 0 & w & w & n.t. & n.t. & in.t. & n.t. \\
\hline & Zinc phosphate $20 \%$ & - & $8(s)$ & 6(s) & 6(s) & - & $8(s)$ & $4(s)$ & $0(s)$ & 6(s) & 0 & w & w & $3(s)$ & 0 & w & w & 3(s) & 0 & w & w \\
\hline EXPOSI-PRZ (ref) & - $\quad-$ & $5(s)$ & $5(s)$ & $5(s)$ & $5(s)$ & - & $6(\mathrm{E})$ & $2(\mathrm{E})$ & $2(\mathrm{E})$ & d & w & w & w & d & w & w & w & d & w & w & w \\
\hline \multirow{6}{*}{ EXPOSI-PRZ } & Calcium phosphate $5 \%$ & - & - & - & - & - & $6(E)$ & 4 & 2 & - & d & w & w & 9(s) & d & w & w & n.t. & n.t. & n.t. & n.t. \\
\hline & Calcium phosphate $10 \%$ & - & - & - & - & - & 6 & 5 & 5 & 5 & 5 & w & w & 4 & 0 & w & w & n.t. & n.t. & n.t. & n.t. \\
\hline & Zinc-iron phosphate 5\% & - & - & - & - & - & $6(E)$ & $d(E)$ & $d(E)$ & $8(\mathrm{~s})$ & d & w & w & $8(\mathrm{~s})$ & d & w & w & n.t. & n.t. & n.t. & n.t. \\
\hline & Zinc-iron phosphate $10 \%$ & - & - & - & - & - & 2 & w & w & - & $d$ & w & w & - & $d$ & w & w & 6(s) & d & w & w \\
\hline & Zinc phosphate $5 \%$ & - & - & - & - & 6(s) & 0 & w & w & $7(\mathrm{~s})$ & d & w & w & - & $d$ & w & w & n.t. & n.t. & n.t. & n.t. \\
\hline & Zinc phosphate $10 \%$ & - & - & - & - & - & $6(E)$ & $3(E)$ & $2(\mathrm{E})$ & 0 & d & w & w & $8(\mathrm{~s})$ & d & w & w & n.t. & n.t. & n.t. & n.t. \\
\hline
\end{tabular}

W: Withdrawn; (s): scribe; (E): Edge; d: delamination; n.t.: non tested

Table V. Degree of blistering after 3, 6, 12 y 24 months of exposure in the Madrid atmosphere for specimens contaminated with known levels of chlorides

Tabla V. Grado de ampollamiento exhibido por las muestras contaminadas con niveles conocidos de cloruros tras 3, 6, 12 y 24 meses de exposición en la atmósfera de Madrid

\begin{tabular}{|c|c|c|c|c|c|c|c|c|c|c|c|c|c|c|c|c|c|c|c|c|c|}
\hline \multirow{2}{*}{\multicolumn{2}{|c|}{ Systems }} & \multirow{2}{*}{\multicolumn{4}{|c|}{ Level 0}} & \multicolumn{16}{|c|}{ Chlorides level } \\
\hline & & & & & & \multicolumn{4}{|c|}{ C50-100 } & \multicolumn{4}{|c|}{ C100-200 } & \multicolumn{4}{|c|}{ C200-300 } & \multicolumn{4}{|c|}{ C900 } \\
\hline Vehicle & Pigment & $\begin{array}{c}3 \\
\text { months }\end{array}$ & $\begin{array}{c}6 \\
\text { months }\end{array}$ & $\begin{array}{c}12 \\
\text { months }\end{array}$ & $\begin{array}{c}24 \\
\text { months }\end{array}$ & $\begin{array}{c}3 \\
\text { months }\end{array}$ & $\begin{array}{c}6 \\
\text { months }\end{array}$ & $\begin{array}{c}12 \\
\text { months }\end{array}$ & $\begin{array}{c}24 \\
\text { months }\end{array}$ & $\begin{array}{c}3 \\
\text { months }\end{array}$ & $\begin{array}{c}6 \\
\text { months }\end{array}$ & $\begin{array}{c}12 \\
\text { months }\end{array}$ & $\begin{array}{c}24 \\
\text { months }\end{array}$ & $\begin{array}{c}3 \\
\text { months }\end{array}$ & $\begin{array}{c}6 \\
\text { months }\end{array}$ & $\begin{array}{c}12 \\
\text { months }\end{array}$ & $\begin{array}{c}24 \\
\text { months }\end{array}$ & $\begin{array}{c}3 \\
\text { months }\end{array}$ & $\begin{array}{c}6 \\
\text { months }\end{array}$ & $\begin{array}{c}12 \\
\text { months }\end{array}$ & $\begin{array}{c}24 \\
\text { months }\end{array}$ \\
\hline Oil (ref) & red lead oxide & - & - & - & - & - & 9 & 9 & 9 & - & 9 & 8 & 8 & 9 & 8 & 8 & 7 & 8 & 6 & 6 & 6 \\
\hline \multirow{6}{*}{ EXPOSI-NON PRZ } & Calcium phosphate $10 \%$ & - & $7(\mathrm{~s})$ & $6(\mathrm{~s})$ & $6(\mathrm{~s})$ & - & - & - & 9 & n.t. & n.t. & n.t. & n.t. & 9 & 7 & 7 & 7 & n.t. & n.t. & n.t. & n.t. \\
\hline & Calcium phosphate $20 \%$ & - & 9(s) & $6(\mathrm{~s})$ & $4(s)$ & - & 9(s) & 9(s) & $8(\mathrm{~s})$ & n.t. & n.t. & n.t. & n.t. & 9 & 6 & 6 & 6 & n.t. & n.t. & n.t. & n.t. \\
\hline & Zinc-iron phosphate $10 \%$ & - & - & - & - & - & - & 9 & 9 & - & 8 & 7 & 7 & - & 6 & 6 & 6 & 7 & 5 & 5 & w \\
\hline & Zinc-iron phosphate $20 \%$ & - & $8(\mathrm{~s})$ & $7(\mathrm{~s})$ & $6(\mathrm{~s})$ & - & 9 & 9 & $9 / 7(\mathrm{~s})$ & n.t. & n.t. & n.t. & n.t. & - & 7 & 7 & 6 & 7 & 5 & 5 & w \\
\hline & Zinc phosphate $10 \%$ & - & - & $7(s)$ & $7(\mathrm{~s})$ & - & - & - & $9(\mathrm{~s})$ & n.t. & n.t. & n.t. & n.t. & - & 7 & 7 & 6 & n.t. & n.t. & n.t. & n.t. \\
\hline & Zinc phosphate $20 \%$ & - & $8(\mathrm{~s})$ & $6(s)$ & 6(s) & - & - & - & - & n.t. & n.t. & n.t. & n.t. & 9(s) & 7 & 6 & 6 & 9 & 5 & 4 & 2 \\
\hline EXPOSI-PRZ (ref) & $-\quad-$ & $5(\mathrm{~s})$ & $5(s)$ & $5(\mathrm{~s})$ & $5(s)$ & 9 & 9 & 9 & 9 & n.t. & n.t. & n.t. & n.t. & 7 & 7 & 7 & 7 & $7(\mathrm{E})$ & $5(\mathrm{E})$ & $8 / 5(\mathrm{E})$ & $7 / 5(\mathrm{E})$ \\
\hline \multirow{6}{*}{ EXPOSI-PRZ } & Calcium phosphate $5 \%$ & - & - & - & - & - & - & - & - & n.t. & n.t. & n.t. & n.t. & - & - & - & - & n.t. & n.t. & n.t. & n.t. \\
\hline & Calcium phosphate $10 \%$ & - & - & - & - & - & - & - & - & n.t. & n.t. & n.t. & n.t. & - & 9 & 9 & 9 & n.t. & n.t. & n.t. & n.t. \\
\hline & Zinc-iron phosphate $5 \%$ & - & - & - & - & - & - & - & - & - & - & 9 & 9 & - & 9 & 9 & 9 & n.t. & n.t. & n.t. & n.t. \\
\hline & Zinc-iron phosphate $10 \%$ & - & - & - & - & - & 9 & 9 & 9 & n.t. & n.t. & n.t. & n.t. & - & - & 9 & 9 & - & - & - & - \\
\hline & Zinc phosphate $5 \%$ & - & - & - & - & - & - & - & - & n.t. & n.t. & n.t. & n.t. & - & - & - & 9 & n.t. & n.t. & n.t. & n.t. \\
\hline & Zinc phosphate $10 \%$ & - & - & - & - & - & - & - & - & n.t. & n.t. & n.t. & n.t. & - & - & - & - & n.t. & n.t. & n.t. & n.t. \\
\hline
\end{tabular}

W: Withdrawn; (s): scribe; (E): Edge; d: delamination; n.t.: non tested 
For the case of sulphates it was not possible to obtain relevant results at comparative level, either between the ZRP and non-ZRP systems or between the co-pigmented systems and reference systems. This is due to the fact that after $1500 \mathrm{mg} / \mathrm{m}^{2}$ all the primers presented an important degree of blistering and undercutting after only 3 months of exposure, above all in the proximity of the scribe and at the edges. This undercutting, which started at the edges and at the scribe, evolved to complete delamination of the paint coating on most specimens after this level, and for this reason they were withdrawn after 6 months. None of the primers tested seems to tolerate the level of $500 \mathrm{mg} / \mathrm{m}^{2}$ either. Though complete delamination of the coating was not observed, all the primers present significant blistering and in some cases undercutting at the edges and at the scribe. Furthermore, in the case of the ZRPs, some points of rust are already perceptible on the surface after 6 months of exposure.

However, for the case of chlorides certain differences have been found between the different systems. In the case of the ZRPs differences are observed, for all the tested levels, between the copigmented systems and the reference system. Up to the level of $200-300 \mathrm{mg} / \mathrm{m}^{2}$, and even for the only system tested at the level of $900 \mathrm{mg} / \mathrm{m}^{2}$, the copigmented ZRP systems did not present significant deterioration, unlike the ZRP reference system. The co-pigments permit an increase in the critical chloride levels tolerated. Among them, the best behaviour is provided by zinc phosphate and calcium phosphate.

This does not occur with the non-ZRP systems, where the behaviour of the co-pigmented primers is very similar to that of the red lead primer, selected as reference, presenting notable problems after the level of $200-300 \mathrm{mg} / \mathrm{m}^{2}$. Despite this, the best behaviour in the non-ZRP systems is also offered by the zinc phosphate and calcium phosphate pigments.

\subsection{Accelerated humidity condensation test}

Tables VI and VII indicate the degree of blistering of the paint systems after different numbers of condensation cycles. The values of the size and frequency of blisters, according to ASTM standard D-714 ${ }^{[15]}$, have been converted into numeric values using the Keane conversion table ${ }^{[16]}$.
In general, worse behaviour is seen with the non-ZRP systems than with the ZRP systems, and there is a notable improvement in the case of the latter with the co-pigmented systems compared to the ZRP reference system. Also in this case the best behaviour is provided by the zinc phosphate and calcium phosphate pigments, though in the latter case rust stains appear on the exposed surface at many levels, especially in the conditions of maximum pigment concentration.

For the case of chlorides, the co-pigmented ZRPs do not present important blistering problems for levels below $200-300 \mathrm{mg} / \mathrm{m}^{2}$, or with the only system tested at the level of $900 \mathrm{mg} / \mathrm{m}^{2}$, at least up to 7 cycles or even up to 16 cycles in some cases.

For the case of sulphates, it is also the ZRPs copigmented with zinc and calcium phosphate that show the best behaviour, in most cases improving on the behaviour of the reference system. After the level of $2500 \mathrm{mg} / \mathrm{m}^{2}$ all the systems show signs of deterioration during the first test cycles. The non-ZRP systems do not offer a significantly worse behaviour than the ZRP systems, though the specimens of the system co-pigmented with zinc phosphate offer better results than the rest, including the reference red lead.

\section{CONCLUSIONS}

- It is possible to achieve the laboratory contamination of specimens with predetermined chloride and sulphate levels using salt fog and Kesternich type cabinets, obtaining a more similar distribution of contaminants on the rust to that which takes place in the atmosphere.

- ZRPs are an acceptable solution, both from the point of view of anticorrosive protection and from the ecological standpoint, when applied on rusted steel substrates contaminated with up to certain levels of chlorides and sulphates.

- The addition of phosphate type co-pigments improves the behaviour of ZRPs, especially in the case of zinc phosphate, and thus makes it possible to increase critical saline contamination levels. The worst behaviour was provided by zinc-iron phosphate, while calcium phosphate showed intermediate results.

- With regard to co-pigment concentration, the best results were obtained at the maximum concentration tested, which was $10 \%$, especially in the case of zinc phosphate. 


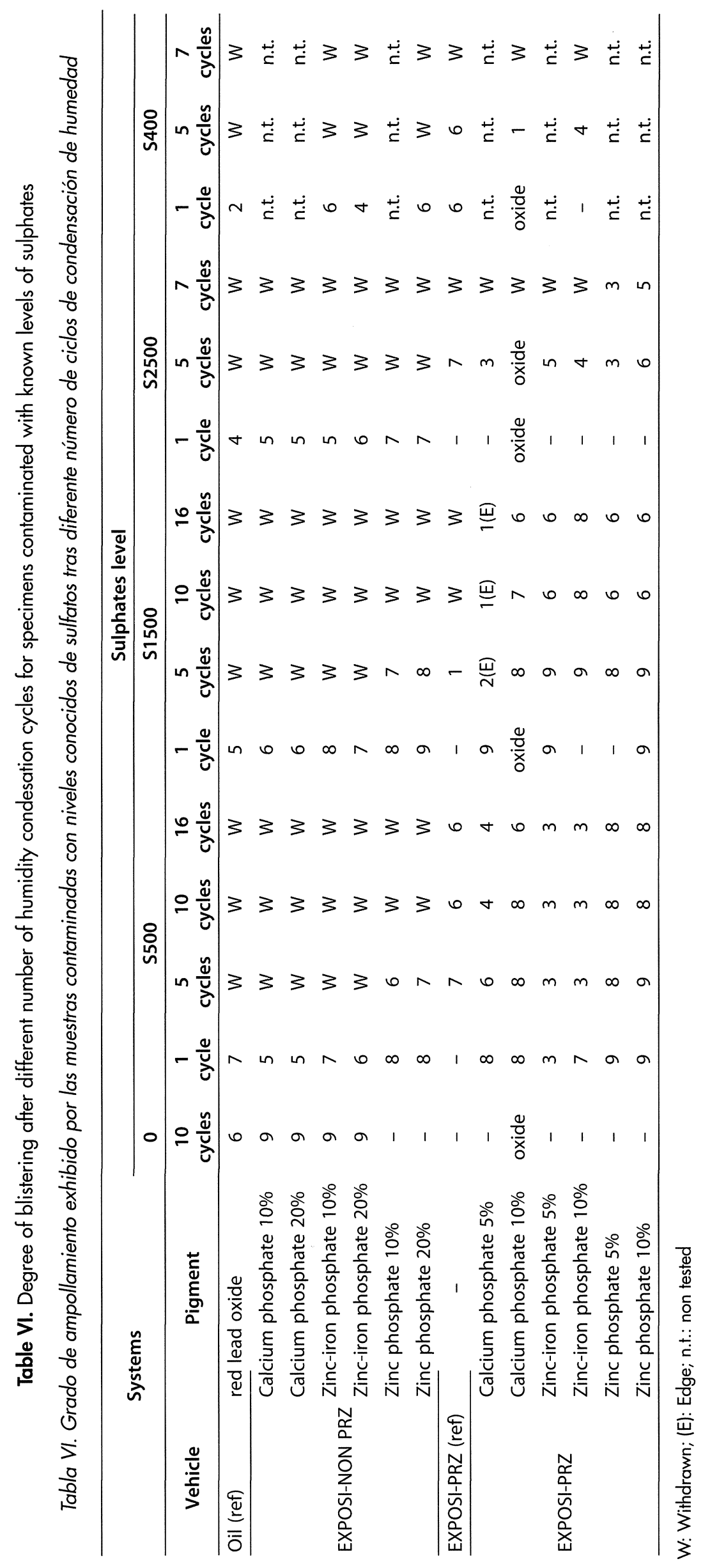




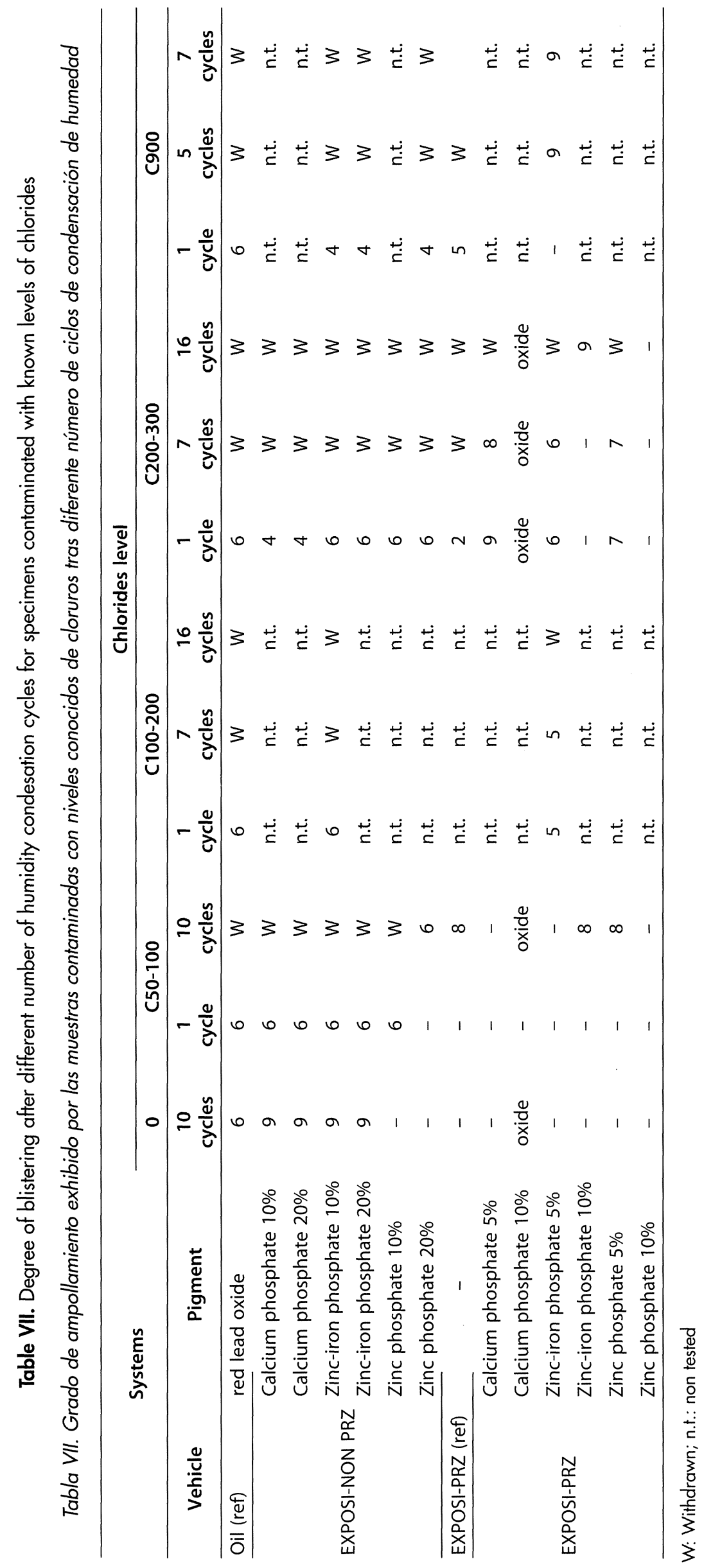


Use of zinc-rich primers co-pigmented with phosphates applied on rusty steel surfaces contaminated with soluble salts D. DE la Fuente, B. Chico y M. Morcillo

\section{Acknowledgements}

The authors of this paper would like to express their gratitude to David Antón, Miguel A. Castadot, Mercedes Merchán and Enrique Palma for their collaboration in the different stages of the research. They also thank the companies Colores Hispania, Pinturas Hempel and Ameron Coatings for supplying the different paints tested.

\section{REFERENCES}

[1] J.E.O. Mayne, J. Appl. Chem. 9 (1959) 673-680.

[2] U.R. Evans and C.A.J. TAYLOR, Trans. Inst. Met. Finish 39 (1962) 188-197.

[3] U.R. Evans and C.A.J. TaYLoR, Trans. Inst. Met. Finish 43 (1965) 169-178.

[4] D. Dasgupta and T.K. Ross, Br. Corros. J. 6 (1971) 241 243.

[5] K.A. Haagenson and R.T. Ross, Pigm. Resin Technol., July (1979) 5-13.

[6] M. Morcillo, S. Feliu, J.C. Galván and J.M. Bastidas, J. Oil. Colour. Chem. Assoc. 71 (1988) 1-25.
[7] M. Morcillo and J. Simancas, J. Protect. Coat. Linings 14 9 (1997).

[8] M. Morcillo and J. Simancas, Proc. PCE'97, The Hague, March 12, 1997, paper $\mathrm{n}^{\circ} 12$.

[9] D.A. Bayliss and K.A. Chandler, Steelwork Corrosion Control, Elsevier, UK, 1991, p.28.

[10] DIN 50021: Spray tests with different sodium chloride solutions, DIN, 1988.

[11] DIN 50018: Testing of Materials Structural Component and Equipment (Method of Test in Damp Heat Alternating Atmosphere in Sulfur Dioxide), DIN.

[12] ASTM D-516: Standard Test Methods for Sulfate Ion in Water and Waste Water, ASTM, 1968.

[13] DIN 53167: Testing of Paints, Varnishes and similar Coatings Materials; Salt Spray Test on Paint Coating and Similar Coatings, DIN, 1983.

[14] ISO 9223: Corrosion of Metals and aAloys. Corrosivity of Atmospheres, ISO, 1992.

[15] ASTM D-714: Evaluating Degree of Blistering of Paints, ASTM, 1987.

[16] J.D. Keane, J.A. Bruno and R.E.F. Weaver, Performance of alternate coatings in the environment, Steel Structure Painting Council, Pittsburgh, 1979. 